\title{
Notes on the vocalizations of Tricolored Brush-finch (Atlapetes tricolor)
}

Peter Boesman

In the following we briefly analyze and compare voice of the two races of Tricolored Brushfinch (Atlapetes tricolor). We also try to quantify the extent of any vocal differences using the criteria proposed by Tobias et al. (2010), as a support for taxonomic review.

We have made use of sound recordings available on-line from Xeno Canto (XC).

Race crassus: Song is quite variable: phrase typically starts with a few melodious whistles, often doubled, and ends with a series of fast repeated notes.

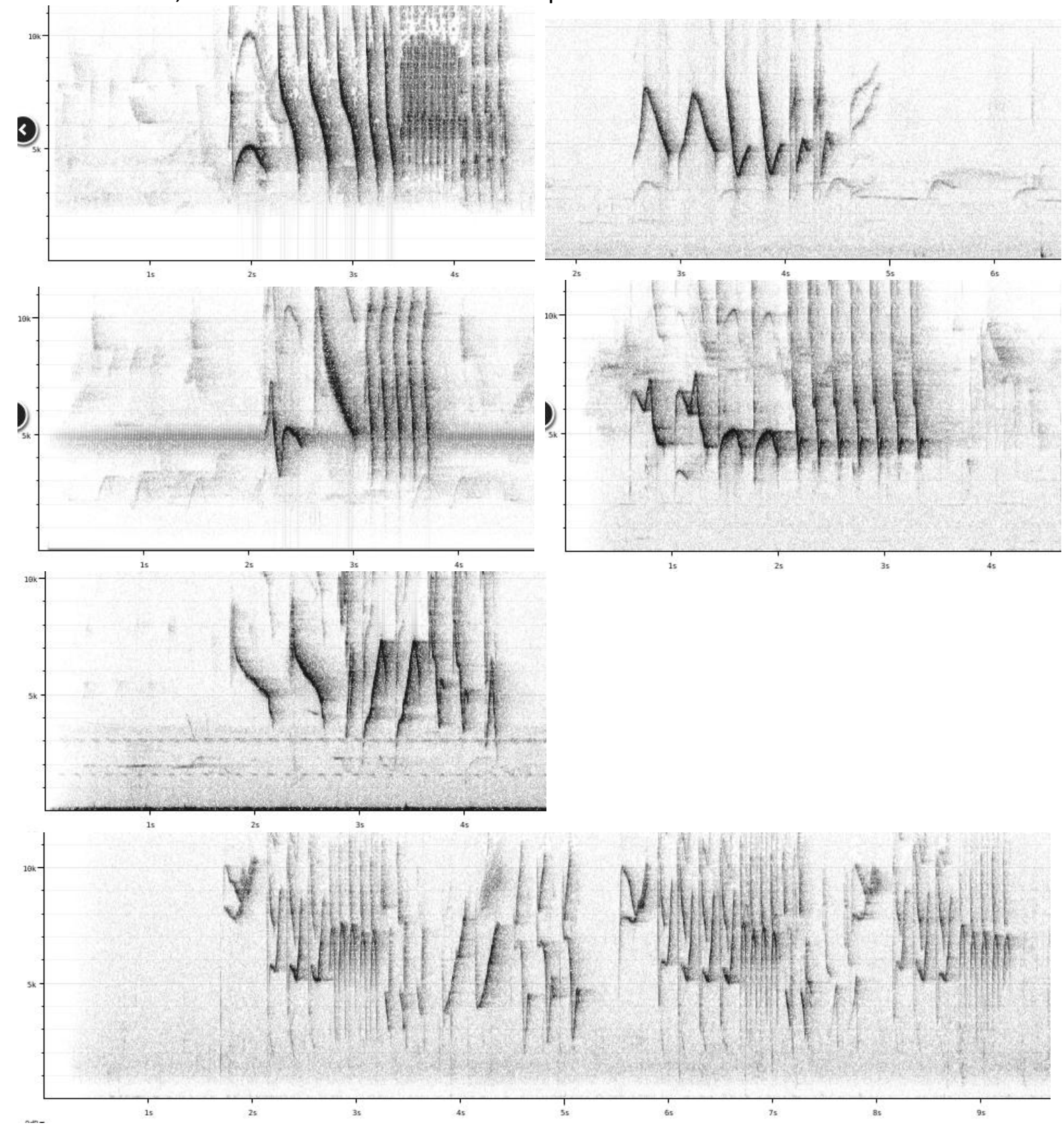




\section{HANDBOOK OF THE \\ wion $A$ thes woun \\ Alve}

\section{ORNITHOLOGICAL NOTES}

Race tricolor: Song is quite variable: phrases typically consist of a few melodious notes, occasionally followed by several notes repeated.
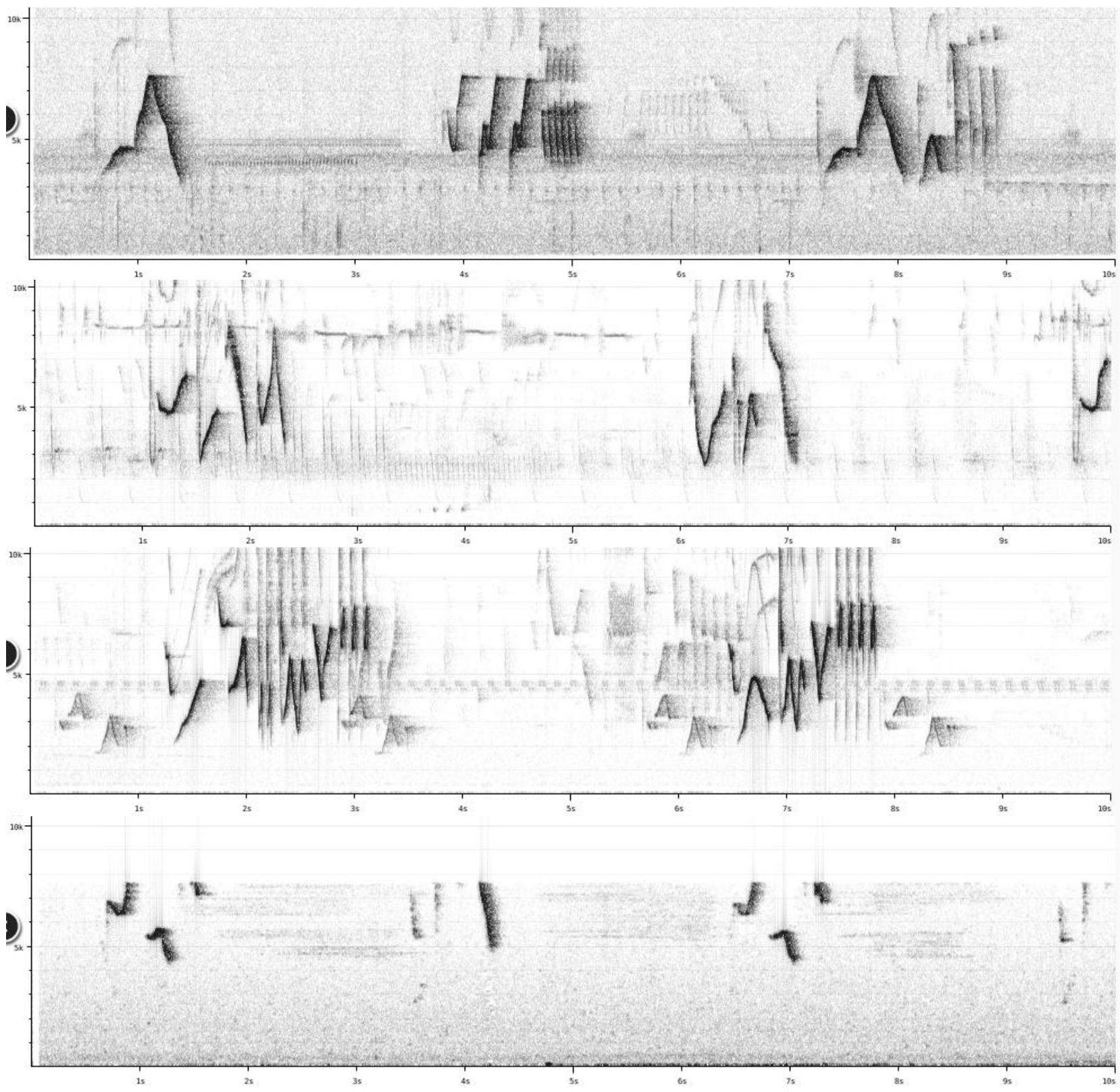

Main differences between song of both races apparently are the duration of the song phrase and the number of notes/phrase (resp. longer and higher in crassus).

These parameters were already measured in Sánchez-González et al. (2015). 

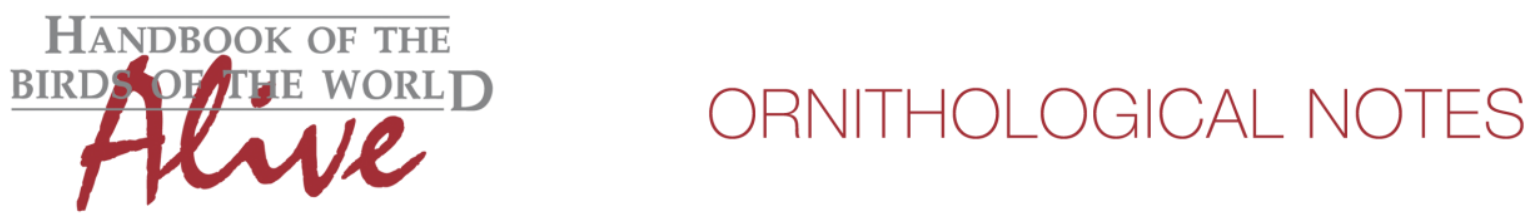

Based on these data, we can calculate effect size:

$\begin{array}{lllll} & \text { crassus } & \text { tricolor } & \text { Effect Size } & \text { Score } \\ \text { phrase duration (s) } & 2.4 \pm 0.5 & 1.4 \pm 0.4 & 2.2 & 2 \\ \text { \# notes/phrase } & 12 \pm 4.5 & 7.3 \pm 4.3 & 1.07 & 1\end{array}$

When applying Tobias criteria, this leads to a total vocal score of 3.

This note was finalized on 25th May 2016, using sound recordings available on-line at that moment. We would like to thank in particular the sound recordists who placed their recordings for this species on XC: Roger AhIman, Nick Athanas, Peter Boesman, Tayler Brooks, Eric DeFonso, Fabian Ducry, David Edwards, Jerome Fischer, David Geale, Wouter Halfwrk, Niels Krabbe, Dan Lane, Oscar Laverde, Mitch Leisinger, Hans Matheve, Patricio Mena Valenzuela, Jeremy Minns, John V Moore, Scott Olmstead, Andrew Spencer and Julian Zuleta Marin.

\section{References}

Sánchez-González, L.A., Navarro-Sigüenza, A.G., Krabbe, N.K., Fjeldså, J., García-Moreno, J. (2015). Diversification in the Andes: the Atlapetes brush-finches. Zool. Scripta 44(2): 135152.

Tobias, J.A., Seddon, N., Spottiswoode, C.N., Pilgrim, J.D., Fishpool, L.D.C. \& Collar, N.J. (2010). Quantitative criteria for species delimitation. Ibis 152(4): 724-746.

\section{Recommended citation}

Boesman, P. (2016). Notes on the vocalizations of Tricolored Brush-finch (Atlapetes tricolor). HBW Alive Ornithological Note 365. In: Handbook of the Birds of the World Alive. Lynx Edicions, Barcelona. (retrieved from http://www.hbw.com/node/1252910 on 2 November 2016). 